\title{
CANTIGA DOS BECOS DE ANTÔNIO DIAS
}

Daniel Moreira $^{1}$

Pelos becos de Antônio Dias,

o chão molhado, as sombras frias,

repousa minha Ouro Preto.

Esse casario,

essas ruas tortuosas

se derramando pelos morros,

os fundos de quintais - mundos possíveis e inumeráveis.

O declive natural

leva ao chafariz de Marília,

cruzando a Ponte do Suspiro.

Tudo chama a uma herança

que não tenho,

mas que sempre supus minha.

(Minha família em que se sabe,

quando muito, o primeiro nome de bisavós...)

As ruas com dois, três nomes cada,

trezentos anos de vidas

se encontrando,

se sobrepondo,

nesse mesmo chão.

Entrar nessas igrejas todas

mal sabendo de deus...

Nossa Senhora da Conceição de Antônio Dias,

o corpo de Aleijadinho

aí repousa,

à igreja de São Francisco de Assis

coube sua alma.

Pelas ruas de Antônio Dias,

o sol tão logo se apruma,

o ar se liquefaz em brumas...

Ouro Preto, 2008.

\footnotetext{
${ }^{1}$ Doutor em Letras: Estudos Literários pela Universidade Federal de Juiz de Fora.
} 


\title{
VIAGEM
}

\section{Daniel Moreira}

\author{
Longe de casa \\ tudo soa \\ mais poético. \\ O país \\ de tal modo imenso... \\ Deixar de ser estrangeiro \\ na própria terra. \\ Poucas estradas \\ passam sob o corpo \\ inerte \\ e já sou outro.
}

Ouro Preto, 2008. 


\section{NOTA TIPOGRÁFICA}

Daniel Moreira

Essa pessoa foi composta em caracteres vacilantes, corpo que se equilibra entre real e inventado, impressa em carne densa para dificultar a leitura.

Juiz de Fora, 20 ago. 2009. 